\title{
Reconstruction of Thermal Conditions in the Subboreal Inferred from Isotopic Studies of Groundwater and Calcareous Tufa from the Spring Mire Cupola in Wardzyń (Central Poland)
}

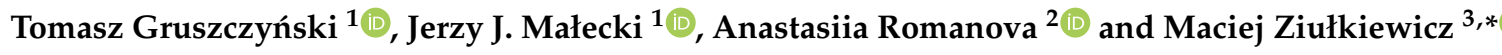 \\ 1 Institute of Hydrogeology and Engineering Geology, University of Warsaw, Żwirki i Wigury St. 93, \\ 02-089 Warszawa, Poland; tgruszcz@uw.edu.pl (T.G.); jerzy.malecki@uw.edu.pl (J.J.M.) \\ 2 Institute of Geological Sciences, Polish Academy of Sciences, Twarda St. 51/55, 00-818 Warszawa, \\ Poland; a.romanova@twarda.pan.pl \\ 3 Laboratory of Geology, University of Łódź, Kopcińskiego St. 31, 90-142 Łódź, Poland \\ * Correspondence: maciej.ziulkiewicz@geo.uni.lodz.pl
}

Received: 14 August 2019; Accepted: 12 September 2019; Published: 19 September 2019

\begin{abstract}
Studies with application of stable isotopes of oxygen and carbon have been performed on calcareous tufa, groundwater and dissolved inorganic carbon (DIC) from the spring mire cupola in Wardzyń. This study was focused on the verification of the a priori hypothesis that the analysed calcareous tufa is a chemical deposit and on the attempt to supplement an earlier scenario of environmental changes in the Subboreal with oscillations of water temperature. The constructed model of chemical and isotope balance, and $\delta^{13} \mathrm{C}$ determinations in DIC, allowed for calculating ratios of stable isotopes of carbon in particular speciations and in gaseous $\mathrm{CO}_{2}$. The obtained results coupled with $\delta^{13} \mathrm{C}$ values in calcite indicate that this mineral precipitated from the solution chemically (without the contribution of living organisms). Additionally, it was possible to reconstruct the temperature range at which the calcareous tufa was formed. The reconstructed scenario of changes in the thermal conditions was refined based on $\delta^{18} \mathrm{O}$ determinations in groundwater and calcite. Accordingly, the oldest calcareous tufa, with an age of about 5500 cal years BP, was formed in cool climate conditions (with average annual temperatures by about $3{ }^{\circ} \mathrm{C}$ lower than presently). The formation of younger series of the calcareous tufa took place between 4400-2900 cal years BP and represents a much warmer period with two distinct cooler episodes at 3900 and 3000 cal years BP, respectively. The course of the obtained temperature curves correlates well with the GISP2 curve and curves obtained for other sites in Northern, and Central Europe.
\end{abstract}

Keywords: climate change; paleohydrology; stable isotopes; Poland

\section{Introduction}

Climate changes over the Holocene are a field of interest for researchers representing various branches of science from the beginning of the 20th century. These studies are of particular importance as they help to better understand the mechanism of recent climate change and can provide important premises for further changes forecasting. Interpretation of changes in climate parameters, in particular air temperature, is possible thanks to the analysis of marine and terrestrial sediments [1] and ice cores extracted from glaciers [2,3]. There is a number of indicators of climate change in deposits such as pollen (e.g. [4]) or macrofossils found in peat (e.g. [5]). An important carrier of information about climate changes are stable carbon isotopes $\delta^{13} \mathrm{C}$ and $\delta^{18} \mathrm{O}$ in endogenous calcite (tufa deposits), which were used among others to reconstruct Holocene climatic changes in southern Poland [6] and in the 
Bohemian Karst [7]. The isotopic composition of fine-grained calcite from lake sediments were used to reflecting variations in the precipitation seasonality in the Baltic region as evidence of changes in North Atlantic ocean-atmospheric circulation [8]. However, apart from information on the variability of climatic conditions, it is necessarily for palaeoclimatic reconstruction to refer registered changes to the time axis. The above conditions were fulfilled for the sediment series of mire spring cupola in Wardzyń.

The spring mire cupola in Wardzyń represents an accumulation of hydrogenic and chemical deposits, genetically related with a set of groundwater springs located in the marginal zone of the Wolbórka valley. Previous studies of the cupola [9] have allowed for distinguishing four levels of calcareous tufa, predominantly composed of calcite separated by peat layers. Radiocarbon dates of the peat indicate that the carbonate horizons were formed from about $5500 \mathrm{cal}$ years BP to about $2900 \mathrm{cal}$ years BP, and the lithological features and mineralogical composition of the deposits record changes of environmental conditions in the Subboreal. The succession of strata and the mineral composition of the deposits has allowed for linking the calcareous tufa formation with dry episodes, with the peat layers representing intervals with elevated annual precipitation [9]. This study applies determinations of stable isotopes of carbon and oxygen in calcite, coupled with ${ }^{18} \mathrm{O} /{ }^{16} \mathrm{O}$ ratios determined in groundwater and ${ }^{13} \mathrm{C} /{ }^{12} \mathrm{C}$ ratios determined in DIC. Calcite is the most commonly used carbonate in paleoenvironmental reconstructions. It precipitates in the aquatic environment as a result of carbonate imbalance. Calcite precipitation is accompanied by the fractionation of stable carbon and oxygen isotopes. The main factor determining the isotope fractionation (especially in the case of oxygen) is the water temperature. On this basis, by determining stable isotopes in calcite, one can reconstruct how the temperature of the water changed during the precipitation of this mineral from the aqueous solution.

The $\delta^{13} \mathrm{C}$ composition of various carbon pools is a tracer for the origin of carbon and contributes to understanding the global carbon cycle in the context of the climate change and the global worming effects. The $\delta^{18} \mathrm{O}$ of carbonates preserves a record of the ${ }^{18} \mathrm{O} /{ }^{16} \mathrm{O}$ composition of the water from which the calcite is precipitated and allows to determine the temperature of precipitation process; this led to formulation of the $\delta^{18} \mathrm{O}_{\mathrm{CaCO} 3}$ paleotemperature scale [10].

Terrestrial or freshwater carbonates, including spelothem, travertine, calcrete and secondary mineralization in soli and near surface fractures, precipitate from groundwaters at or near the point of discharge. The geochemical processes that initiate calcite precipitation can include depressurization and $\mathrm{CO}_{2}$ degassing (e.g. spelothem and travertine), evaporation (e.g. soil calcrete), freezing of bicarbonate waters, sulfate reduction and other biotic reactions [11]. Their $\mathrm{C}$ and $\mathrm{O}$ isotopic composition is a reflection of the geochemical and climatic (i.e. mainly temperature) conditions during precipitation, and can be used to interpret their origin.

In fact, there are two temperatures recorded by the $\delta^{18} \mathrm{O}$ of freshwater calcite: (i) the water temperature at which precipitation took place-i.e. the temperature of equilibrium fractionation between water and calcite, and (ii) the climatic temperature (i.e. mean annual air temperature) recorded by the $\delta^{18} \mathrm{O}$ of water according to the local T- $\delta^{18} \mathrm{O}$ relationship [11].

The main focus of these investigations was to verify the a priori hypothesis that the analysed calcareous tufa is a chemical deposit and to supplement an earlier scenario of environmental changes in the Subboreal with oscillations of water temperature determined in the spring zone.

\section{Materials and Methods}

\subsection{Study Area}

The spring mire cupola in Wardzyn is located along the margin of the moraine plateau (Romanowskie Hills) within a depression assigned to the polygenic valley of upper Wolbórka (Figure 1). The cupola covers an area of about 1.5 ha. At present, 20 permanent springs function within it; their total discharge varies within 10.5-16.5 l/s. The spring deposits infill an erosional incision, which is an elongation of a small dry valley visible in the plateau morphology. The cupola is composed 
of peats with 1 to a maximum of 4 layers of calcareous tufa [9]. These deposits with a total thickness reaching $3.5 \mathrm{~m}$ lie directly on medium-and multi-grained fluvial sands (Figure 2). The oldest calcareous tufa (series A) was probably formed at the end of the Atlantic period. Determination of its precise date is not possible due to the lack of organic deposits in its base, however the radiocarbon age of peat covering this calcareous tufa indicates its formation before $4600 \pm 60$ years BP. The tufa is composed of calcite encrusting plant remains. Sediments of series A occur only within the erosional incision. Above lies a layer of strongly decomposed peat with high contribution of calcium carbonate and detritic material (mainly quartz). Locally these deposits pass laterally into mineral deposits developed as silts. Younger series of the calcareous tufa occur in a narrow, elongated zone, whose orientation corresponds to the axis of the erosional incision of the substratum. The largest thicknesses (locally exceeding $1 \mathrm{~m}$ ) are attained by these deposits in the southern and central part of the analysed cupola. Three series of calcareous tufa (B, C and D) can be distinguished here, being separated by peat layers. In the north they represent usually over ten centimetres thick interbeds of calcium carbonate within peats. In the marginal zones of calcareous tufa occurrence and in the topmost part of the cupola the deposits represent rhythmites. The tufas are covered by a layer of reed-wood peat, strongly decomposed in its topmost part.

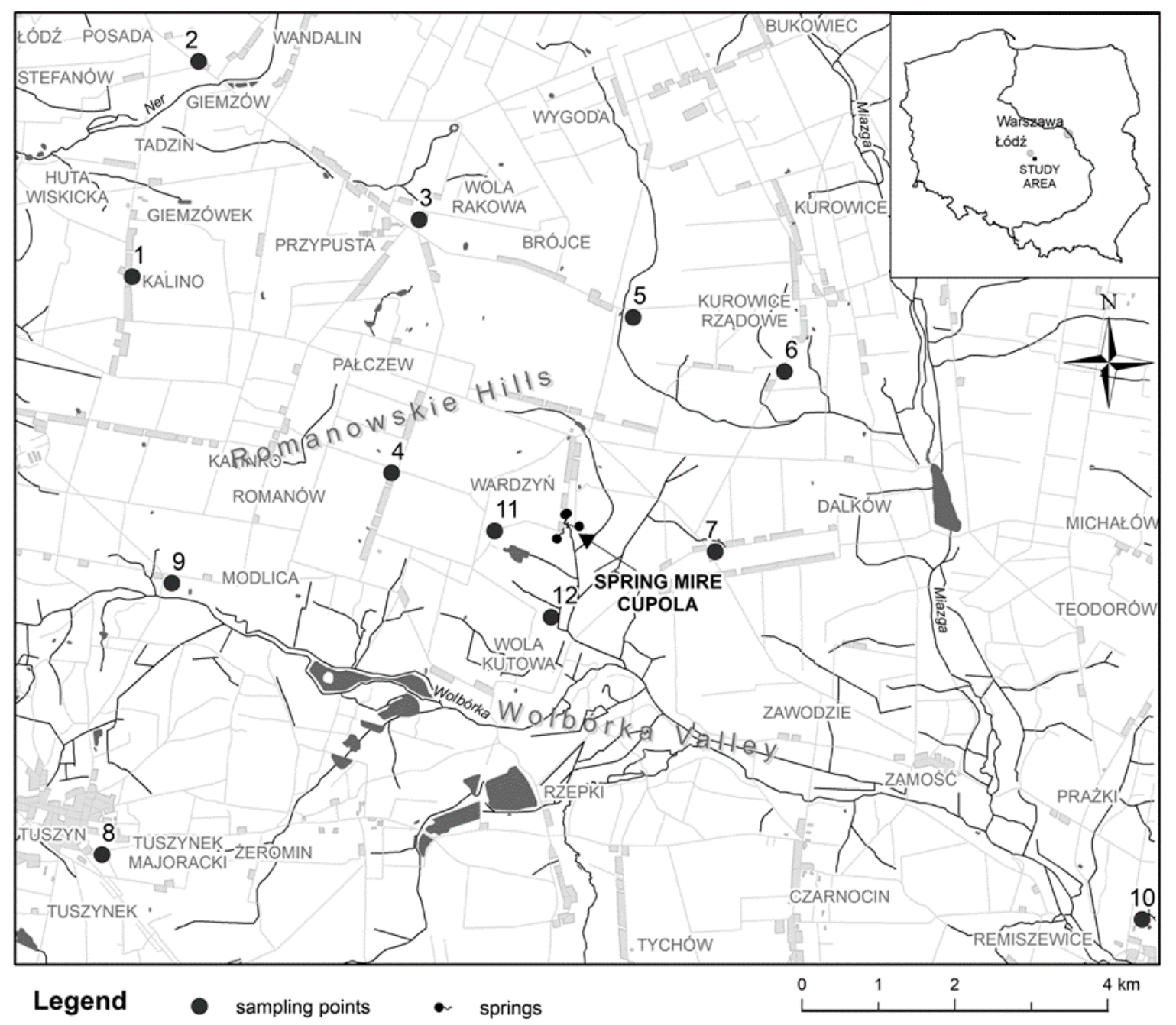

Figure 1. Location sketch-map.

Groundwater springs in the vicinity of the cupola are hydrodynamically related with a shallow aquifer system comprising Cenozoic and the topmost part of Mesozoic formations. The Cenozoic formation was formed as a result of processes related with the advance and retreat of the Scandinavian 
ice-sheets, and fluvial and lacustrine accumulation in the interglacials. The variable origin of Quaternary deposits and the variable energy of the sedimentary environment have caused that this formation is highly heterogeneous. The aquifer horizons attain diverse thicknesses and may locally be discontinuous. The filtration parameters of the deposits also vary in space. The richest aquifer horizons are linked with fluvioglacial sediments, and fluvial and lacustrine sands, which according to the stratigraphic scheme by Marks et al. [12] represent the complex of Middle Polish Glaciations. These deposits form an aquifer attaining a thickness of up to $35 \mathrm{~m}$. The medium is siliceous and the material includes also numerous grains of carbonate rocks (mainly Palaeozoic limestones). Locally the horizon is bipartite, and the subdividing layer includes glacial tills and ice-dammed deposits. The aquifer sediments are characterised by good permeability. The values of hydraulic conductivity determined on the basis of pumping tests are within $2.7 \times 10^{-5}$ to $3.0 \times 10^{-4} \mathrm{~m} / \mathrm{s}$ [13]. The lower part of the Quaternary formation represented by deposits of South Polish Glaciations is dominated by poorly permeable deposits (ice-dammed clays and glacial tills). These deposits together with the Neogene weathering cover form the aquitard. Below occur aquifer deposits of the Mesozoic formation assigned to the Łódź Trough. Wardzyń is located in the southern part of the small Łódź Trough-a syncline with a SSW-NNW-oriented axis. Faults with an orientation perpendicular to the syncline axis occur within it, resulting in a block structure of the trough. Aquifer is linked with Upper Cretaceous limestones, marls and opokas. These deposits are usually characterised by good permeability, and the hydraulic conductivities within the sub-Cenozoic basement are between $2.0 \times 10^{-5}$ and $1.8 \times 10^{-4} \mathrm{~m} / \mathrm{s}$ [13].

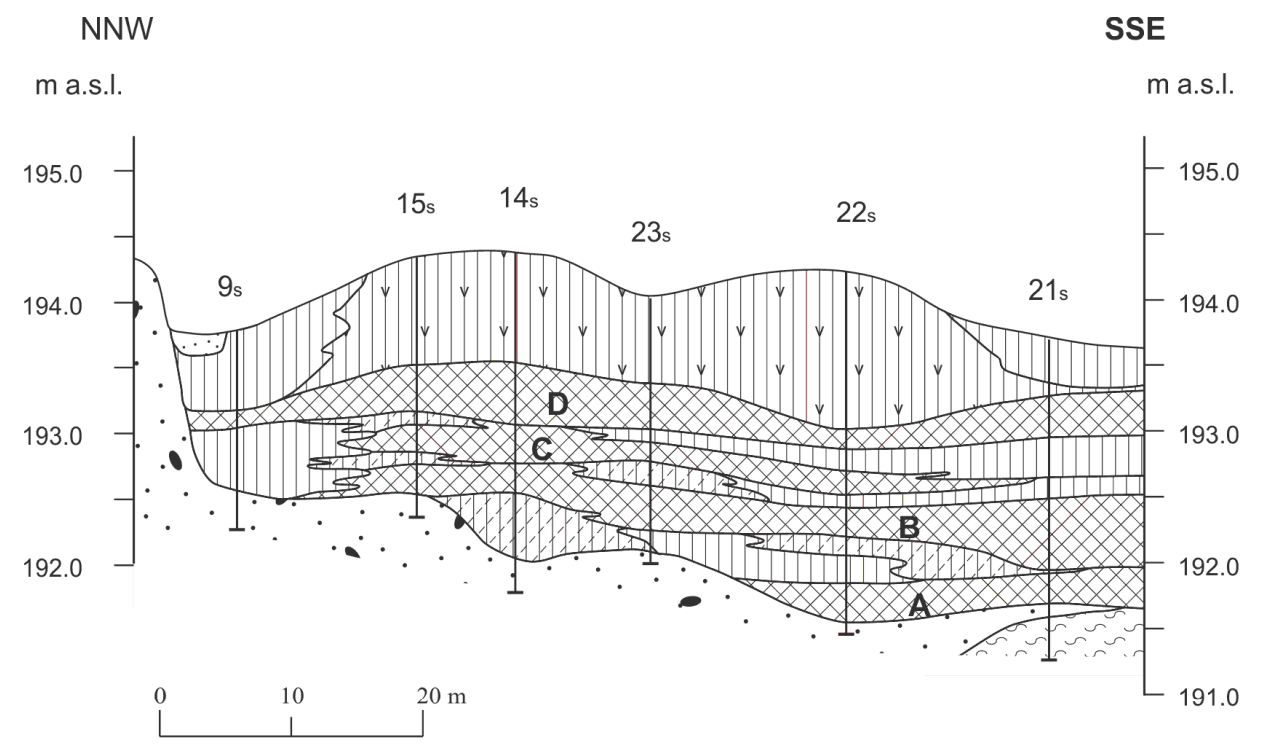

Legend:
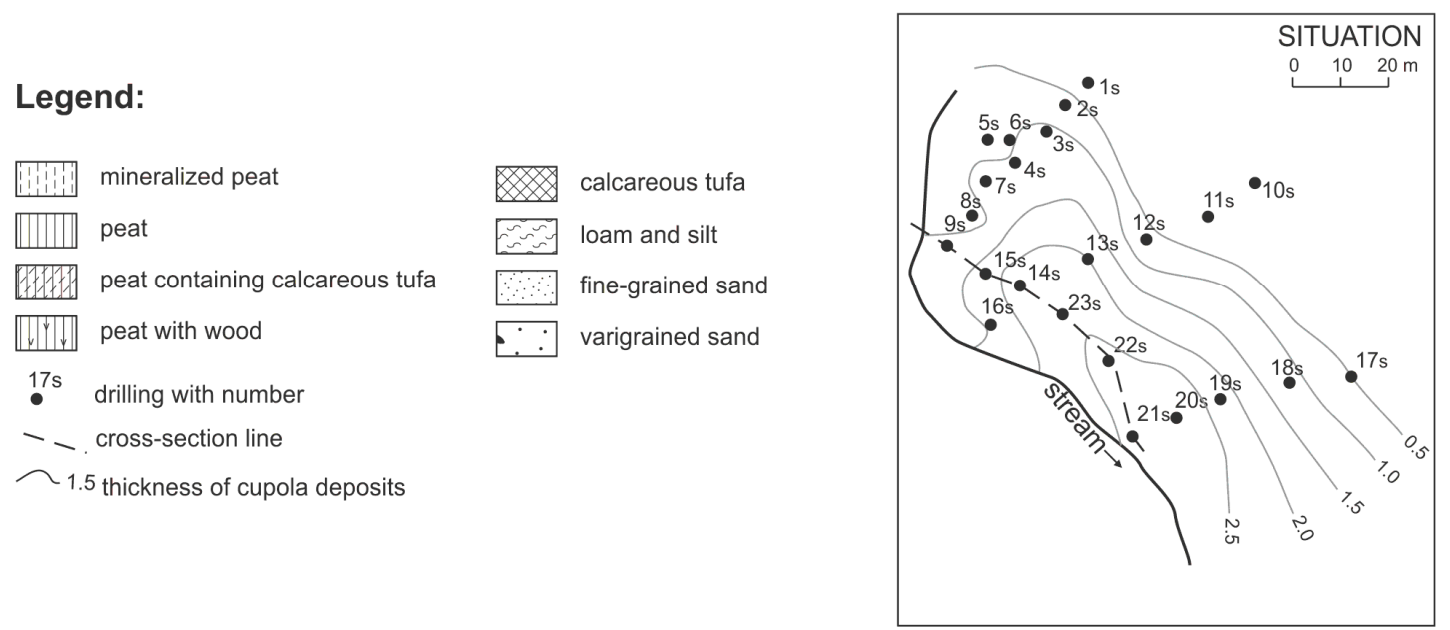

Figure 2. Schematic cross-section through the deposits of the spring mire cupola in Wardzyń. 


\subsection{Sampling and Analytical Methods}

Water samples were collected from wells (samples 1-10) during their continuous exploitation. The water sample from the Wardzyń spring (11) was collected directly from the outflow from the peat zone, sample (12) was collected from a negative pressure probe with a $0.3 \mathrm{~m}$ long active teflon bit. Water temperature, $\mathrm{pH}$, redox potential, and SEC were measured directly in the field; the content of free $\mathrm{CO}_{2}$ was determined by sodium hydroxide titration against phenylophtaleine. Water samples for chemical analyses were collected in single PE bottles, filtered through a $0.45 \mu \mathrm{m}$ pore size membrane filter (MCE), and preserved in $\mathrm{HNO}$, if necessary. Analysis of all water samples $\left(\mathrm{Ca}^{2+}, \mathrm{Mg}^{2+}, \mathrm{Na}^{+}, \mathrm{K}^{+}\right)$ involved flame absorption spectrophotometry SpectrAA 300 (Varian, Palo Alto, CA, USA) (detection limit is $0.05 \mathrm{mg} / \mathrm{L}$ ) and UV-vis spectrophotometry S.330 (Marcel, Poland) in the case of $\mathrm{NH}_{4}{ }^{+}, \mathrm{NO}_{2}{ }^{-}$ (d.l. is $0.001 \mathrm{mg} / \mathrm{L}$ ) and $\mathrm{NO}_{3}{ }^{-}$(d.l. is $0,01 \mathrm{mg} / \mathrm{L}$ ). $\mathrm{SO}_{4}{ }^{2-}$ was determined by the gravimetric method (PN-C-04566-09), $\mathrm{Cl}^{-}$by Mohr's method (PN-ISO 9297), and alkalinity according to the PN-ISO 9963-1 method (detection limit is $0.1 \mathrm{mg} / \mathrm{L}$ ). The chemical analyses were performed in the Laboratory of the Department of Geology at the Faculty of Geographical Sciences, University of Łódź and the Laboratory of Computer and Analytical Techniques at the Faculty of Biology and Environmental Protection, University of Łódź.

Ten samples of groundwater from springs and shallow dug wells within the study area were taken for determination of the isotopic composition of oxygen and hydrogen. All waters were collected in $30 \mathrm{ml}$ glass bottles to overflowing and tightly capped to avoid air bellows inside. The ${ }^{18} \mathrm{O} /{ }^{16} \mathrm{O}$ ratios in waters were determined by the $\mathrm{CO}_{2}-\mathrm{H}_{2} \mathrm{O}$ equilibration technique with application of on-line continuous flow Gas Bench II system supported by Combi PAL autosampler (CTC Analytics, Zwingen, Switzerland) and connected to MAT 253 (Thermo Fisher, Germany) isotope ratio mass spectrometer (IRMS). The equilibration process was performed for $18 \mathrm{~h}$ at $32{ }^{\circ} \mathrm{C}$. The ${ }^{2} \mathrm{H} /{ }^{1} \mathrm{H}$ ratios in water samples were determined with application of H-Device automated system equipped with Combi PAL autosampler and connected to MAT 253 IRMS. For mass spectrometric analysis of the ${ }^{2} \mathrm{H} /{ }^{1} \mathrm{H}$ ratio the hydrogen gas was obtained via direct reduction of water on hot chromium in temperature $850^{\circ} \mathrm{C}$. The results were reported using $\delta$ notation with respect to the VSMOW international standard. Normalization of measured data was performed according to three international standards, namely: VSMOW $\left(\delta^{2} \mathrm{H}=0.0 \%\right.$, $\delta^{18} \mathrm{O}=0.0 \%$ o), VSLAP $\left(\delta^{2} \mathrm{H}=-427.5 \%\right.$ o, $\delta^{18} \mathrm{O}=-55.50 \%$ o $)$, and GISP $\left(\delta^{2}=-189.5 \%\right.$ o, $\delta^{18} \mathrm{O}=-24.76 \%$ o). The precision of the $\delta^{18} \mathrm{O}$ and $\delta^{2} \mathrm{H}$ measurements were $\pm 0.1 \%$ o and $\pm 1.0 \%$ respectively.

Twelve samples of water were collected from the same springs and shallow wells for determination of stable carbon isotopic composition of DIC (dissolved inorganic carbon). All waters were collected in $100 \mathrm{ml}$ glass bottles to overflowing, tightly capped to avoid air bellows inside, and additionally capped with parafilm to avoid evaporation and gas exchange during transport. The ${ }^{13} \mathrm{C} /{ }^{12} \mathrm{C}$ ratios of DIC in water samples were determined on the evolved $\mathrm{CO}_{2}$ gas with application of the on-line continuous flow Gas Bench II system equipped with Combi PAL autosampler and connected to MAT 253 IRMS. $\mathrm{CO}_{2}$ gas was evolved from DIC using $>98 \%$ anhydrous $\mathrm{H}_{3} \mathrm{PO}_{4}$ acid and left for $18 \mathrm{~h}$ equilibration at $70{ }^{\circ} \mathrm{C}$ prior to the isotopic analysis.

Thirteen samples of carbonates (i.e. $>98 \%$ calcite) were collected from carbonate domes within the study area for determination of their carbon and oxygen isotope composition. The ${ }^{13} \mathrm{C} /{ }^{12} \mathrm{C}$ and ${ }^{18} \mathrm{O} /{ }^{16} \mathrm{O}$ ratios of calcites were determined on the released $\mathrm{CO}_{2}$ gas with application of the same on-line continuous flow Gas Bench II system connected to MAT 253 IRMS. $\mathrm{CO}_{2}$ gas was released into the vials headspace from solid calcites reacting with concentrated (i.e. $>98 \%$ ), anhydrous $\mathrm{H}_{3} \mathrm{PO}_{4}$ acid at $70{ }^{\circ} \mathrm{C}$ for $1 \mathrm{~h}$. The results of measurements of $\delta^{13} \mathrm{C}$ of DIC, and $\delta^{13} \mathrm{C}$ and $\delta^{18} \mathrm{O}$ of the carbonates were reported with respect to VPDB international standard. Normalization of measured data was performed according to two international standards, namely: NBS-18 (carbonatite: $\delta^{13} \mathrm{C}=-5.01 \%$, $\delta^{18} \mathrm{O}=-23.01 \%$ o) and NBS-19 (limestone: $\delta^{13} \mathrm{C}=+1.95 \%$, $\delta^{18} \mathrm{O}=-2.2 \%$ o). The precision of the $\delta^{13} \mathrm{C}$ and $\delta^{18} \mathrm{O}$ analysis were $\pm 0.1 \%$. The precision of the isotopic measurements was calculated based on long-term measurements of international reference materials. 
The isotopic analysis was performed in the Institute of Geological Sciences of the Polish Academy of Sciences, Warsaw, Poland.

Six peat samples, $50 \mathrm{~g}$ each, were collected from two cores for the radiocarbon analysis. Determinations were made in the Absolute Age Laboratory at Skała. The scintillation technique with the use of a low-background spectrometer was applied, in which benzene obtained from the material containing organic carbon is analysed. In earlier studies, the radiocarbon age was used. In the current study the age was calibrated against the IntCal 13 curve with application of OxCal software, version 4.3 [14].

\subsection{Mathematical Model}

Determination of the temperature of calcium precipitation based on stable isotopes of carbon required calculation of equilibrium values of $\delta^{13} \mathrm{C}$ in relation to the main speciations of carbon dioxide in the solution and gaseous carbon dioxide. Therefore, calculations were based on chemical and isotopic equilibrium, taking into account solution temperature and mass balance. The first stage of the calculations included determination of molar concentrations of $\mathrm{CO}_{3}{ }^{2-}, \mathrm{HCO}_{3}{ }^{-}$and $\mathrm{CO}_{2(\mathrm{aq})}$ in the solution based on the chemical equilibrium model. PHREEQC-2 v. 2.0.53 software [15] was used in the calculations. The input data were results of physical-chemical parameters of the waters. Molar concentrations $m \mathrm{CO}_{3}{ }^{2-}, m \mathrm{HCO}_{3}-$ and $m \mathrm{CO}_{2(\mathrm{aq})}$ calculated by the chemical mass balance model were next applied for calculating $\delta^{13} \mathrm{C}$ in relation to these speciations. It was assumed that DIC concentration in the solution, expressed in moles per litre, includes the sum of moles of stable isotopes of inorganic carbon per litre of solution:

$$
\text { DIC }=m^{13} \mathrm{C}_{\mathrm{DIC}}+m^{12} \mathrm{C}_{\mathrm{DIC}}
$$

This assumption allows to express the $\left[{ }^{13} \mathrm{C} /{ }^{12} \mathrm{C}\right]_{\mathrm{DIC}}$ ratio as:

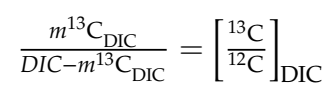

and therefore:

$$
m^{13} \mathrm{C}_{\text {DIC }}=\frac{\left[\frac{13 \mathrm{C}}{12 \mathrm{C}}\right]_{\text {DIC }} \text { DIC }}{1+\left[\frac{13 \mathrm{C}}{12 \mathrm{C}}\right]_{\text {DIC }}}
$$

Analogous equations may be expressed in relation to the main speciation forms of carbon dioxide in the solution, e.g. for $\mathrm{HCO}_{3}{ }^{-}$:

$$
m^{13} \mathrm{C}_{\mathrm{HCO}_{3}}=\frac{\left[\frac{13 \mathrm{C}}{12 \mathrm{C}}\right]_{\mathrm{HCO}_{3}} m \mathrm{HCO}_{3}}{1+\left[\frac{13 \mathrm{C}}{12 \mathrm{C}}\right]_{\mathrm{HCO}_{3}}}
$$

Because in Equation (4) the $\left[{ }^{13} \mathrm{C} /{ }^{12} \mathrm{C}_{\mathrm{HCO}_{3}}\right.$ ratio is the unknown, it is easier to express it by the isotope fractionation ratio in relation to gaseous carbon dioxide $\alpha^{13} \mathrm{C}_{\mathrm{HCO}_{3}-\mathrm{CO}_{2}(\mathrm{~g}) \text { : }}$

$$
m^{13} \mathrm{C}_{\mathrm{HCO}_{3}}=\frac{\alpha_{2}\left[\frac{13 \mathrm{C}}{12 \mathrm{C}}\right]_{\mathrm{OO}_{2}(\mathrm{~g})} m \mathrm{HCO}_{3}}{1+\alpha_{2}\left[\frac{13}{12} \mathrm{C}\right]}
$$

In Equation (5), the $\alpha^{13} \mathrm{C}_{\mathrm{HCO}_{3}-\mathrm{CO}_{2}(\mathrm{~g})}$ ratio was expressed as $\alpha_{2}$ for simplification. Similarly, the fractionation coefficients of carbon stable isotopes among other speciations and the gaseous carbon dioxide are expressed below as $\alpha_{1}$ and $\alpha_{3}$ :

$$
\begin{gathered}
\alpha_{1}=\alpha^{13} \mathrm{C}_{\mathrm{CO}_{3}-\mathrm{CO}_{2}(\mathrm{~g})} \\
\alpha_{2}=\alpha^{13} \mathrm{C}_{\mathrm{HCO}_{3}-\mathrm{CO}_{2}(\mathrm{~g})} \\
\alpha_{3}=\alpha^{13} \mathrm{C}_{\mathrm{CO}_{2}(\mathrm{aq})-\mathrm{CO}_{2}(\mathrm{~g})}
\end{gathered}
$$


Coefficients $\alpha_{1}, \alpha_{2}$ and $\alpha_{3}$ were determined based on the solution temperature $T[\mathrm{~K}]$ and the following equations [16-18]:

$$
\begin{gathered}
10^{3} \ln \alpha_{1}=0.87 \cdot 10^{6} \mathrm{~T}^{-2}-3.4 \\
10^{3} \ln \alpha_{2}=9.552 \cdot 10^{3} \mathrm{~T}^{-1}-24.10 \\
10^{3} \ln \alpha_{3}=-0.373 \cdot 10^{3} \mathrm{~T}^{-1}+0.19
\end{gathered}
$$

Such approach allows on one hand taking into account the thermal conditions of the solution in the calculations, and on the other minimises the number of unknowns in the system of equations, which, in order to calculate the isotope ratio $\left[{ }^{13} \mathrm{C} /{ }^{12} \mathrm{C}_{\mathrm{CO}_{2}(\mathrm{~g})}\right.$ in gaseous carbon dioxide, should be expressed as:

$$
\left\{\begin{array}{c}
m^{13} \mathrm{C}_{\mathrm{CO}_{3}}=\frac{\alpha_{1}\left[\frac{13 \mathrm{C}}{12 \mathrm{C}}\right]_{\mathrm{CO}_{2}(\mathrm{~g})} \cdot m \mathrm{CO}_{3}}{1+\alpha_{1}\left[\frac{13 \mathrm{C}}{12 \mathrm{C}}\right]_{\mathrm{CO}_{2}(\mathrm{~g})}} \\
m^{13} \mathrm{C}_{\mathrm{HCO}_{3}}=\frac{\alpha_{2}\left[\frac{13 \mathrm{C}}{12 \mathrm{C}}\right]_{\mathrm{CO}_{2}(\mathrm{~g})} \cdot m \mathrm{HCO}_{3}}{1+\alpha_{2}\left[\frac{13 \mathrm{C}}{12}\right]_{\mathrm{CO}_{2}(\mathrm{~g})}} \\
m^{13} \mathrm{C}_{\mathrm{CO}_{2}(\mathrm{aq})}=\frac{\alpha_{3}\left[\frac{13 \mathrm{C}}{12}\right]_{\mathrm{CO}_{2}(\mathrm{~g})} m \mathrm{CO}_{2(\mathrm{aq})}}{1+\alpha_{3}\left[\frac{13 \mathrm{C}}{12 \mathrm{C}}\right]_{\mathrm{CO}_{2}(\mathrm{~g})}} \\
m^{13} \mathrm{C}_{\mathrm{DIC}}=m^{13} \mathrm{C}_{\mathrm{CO}_{3}}+m^{13} \mathrm{C}_{\mathrm{HCO}_{3}}+m^{13} \mathrm{C}_{\mathrm{CO}_{2}(\mathrm{aq})}
\end{array}\right.
$$

After substituting the right sides of the first three equations to Equation (4), and transforming it, Equation (9) was obtained, in which, for simplification, unknown $\left[{ }^{13} \mathrm{C} /{ }^{12} \mathrm{C}_{\mathrm{CO}_{2}}\right.$ (g) was expressed as $x$ :

$$
\begin{gathered}
\alpha_{1} \alpha_{2} \alpha_{3}\left({ }^{13} \mathrm{C}_{\mathrm{DIC}}-\left(m \mathrm{CO}_{3}+m \mathrm{HCO}_{3}+m \mathrm{CO}_{2(\mathrm{aq})}\right)\right) x^{3} \\
+\left(\alpha_{1} \alpha_{2}\left({ }^{13} \mathrm{C}_{\mathrm{DIC}}-\left(m \mathrm{CO}_{3}+m \mathrm{HCO}_{3}\right)\right)+\alpha_{2} \alpha_{3}\left({ }^{13} \mathrm{C}_{\mathrm{DIC}}-\left(m \mathrm{HCO}_{3}+m \mathrm{CO}_{2(\mathrm{aq})}\right)\right)\right. \\
\left.+\alpha_{1} \alpha_{3}\left({ }^{13} \mathrm{C}_{\mathrm{DIC}}-\left(m \mathrm{CO}_{3}+m \mathrm{CO}_{2(\mathrm{aq})}\right)\right)\right) x^{2} \\
+\left(\alpha_{1}\left({ }^{13} \mathrm{C}_{\mathrm{DIC}}-m \mathrm{CO}_{3}\right)+\alpha_{2}\left({ }^{13} \mathrm{C}_{\mathrm{DIC}}-m \mathrm{HCO}_{3}\right)+\alpha_{3}\left({ }^{13} \mathrm{C}_{\mathrm{DIC}}-m \mathrm{CO}_{2(\mathrm{aq})}\right)\right) x+{ }^{13} \mathrm{C}_{\mathrm{DIC}} \\
=0
\end{gathered}
$$

It is a cubic equation in the form of:

$$
A x^{3}+B x^{2}+C x+D=0
$$

The coefficients of this equation were determined based on earlier calculated values of fractionation coefficients and molar concentrations for particular speciations. The concentration of isotope ${ }^{13} \mathrm{C}_{\mathrm{DIC}}$ was assumed based on laboratory determinations. After calculating coefficients $A, B, C$ and $D$, the real elements of this equation were determined and thus $x$ was obtained, i.e. $\left[{ }^{13} \mathrm{C} /{ }^{12} \mathrm{C}_{\mathrm{CO}_{2}(\mathrm{~g})}\right.$. Next, based on the following relationships it was possible to calculate $\delta^{13} \mathrm{C}$ for particular speciations:

$$
\delta^{13} \mathrm{C}_{\mathrm{CO}_{2}(\mathrm{~g})}=\left(\frac{\left[\frac{13 \mathrm{C}}{12 \mathrm{C}}\right]_{\mathrm{CO}_{2}(\mathrm{~g})}}{\left[\frac{13 \mathrm{C}}{12 \mathrm{C}}\right]_{\mathrm{VPDB}}}-1\right) \cdot 1000
$$

And

$$
\begin{gathered}
\delta^{13} \mathrm{C}_{\mathrm{CO}_{3}}=\alpha_{1} \delta^{13} \mathrm{C}_{\mathrm{CO}_{2}(\mathrm{~g})}+\alpha_{1} \cdot 1000-1000 \\
{ }^{\delta^{13}} \mathrm{C}_{\mathrm{HCO}_{3}}=\alpha_{2} \delta^{13} \mathrm{C}_{\mathrm{CO}_{2}(\mathrm{~g})}+\alpha_{2} \cdot 1000-1000 \\
\delta^{13} \mathrm{C}_{\mathrm{CO}_{2}(\mathrm{aq})}=\alpha_{3} \delta^{13} \mathrm{C}_{\mathrm{CO}_{2}(\mathrm{~g})}+\alpha_{3} \cdot 1000-1000
\end{gathered}
$$

The calculated values of $\delta^{13} \mathrm{C}_{\mathrm{CO}_{2}(\mathrm{~g})}$ and $\delta^{13} \mathrm{C}_{\mathrm{CaCO}_{3}}$ determinations in calcite obtained from samples of calcareous tufa were used to interpret the thermal conditions of tufa formation. This was achieved by using equation [19]:

$$
10^{3} \ln \alpha_{\mathrm{CO}_{2}(\mathrm{~g})-\mathrm{CaCO}_{3}}=-2.988 \cdot 10^{6} \mathrm{~T}^{-2}+7.6663 \cdot 10^{3} \mathrm{~T}^{-1}-2.4612
$$


At the assumption that calcite precipitation during tufa formation took place in isotope equilibrium conditions, Equation (13) may be used to reconstruct the water temperature. This requires determining the fractionation coefficient from equation:

$$
\alpha_{\mathrm{CO}_{2}(\mathrm{~g})-\mathrm{CaCO}_{3}}=\frac{\delta^{13} \mathrm{C}_{\mathrm{CO}_{2}(\mathrm{~g})}+1000}{\delta^{13} \mathrm{C}_{\mathrm{CaCO}_{3}}+1000}
$$

and transformation of Equation (13) to:

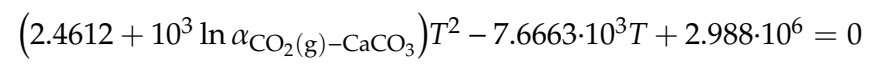

In the value range of $\alpha \mathrm{CO}_{2}(\mathrm{~g})-\mathrm{CaCO}_{3}$ typical for the discussed environment only one element of the equation may be used to reconstruct water temperature; it may be determined from equation:

$$
T\left[{ }^{\circ} \mathrm{C}\right]=\frac{7.6663 \cdot 10^{3}-\sqrt{5.8772 \cdot 10^{7}-2.9416 \cdot 10^{7}-1.1952 \cdot 10^{10} \ln \alpha_{\mathrm{CO}_{2}(\mathrm{~g})-\mathrm{CaCO}_{3}}}}{4.9224+2 \cdot 10^{3} \ln \alpha_{\mathrm{CO}_{2}(\mathrm{~g})-\mathrm{CaCO}_{3}}}-273.15
$$

Additionally, a thermometer based on stable oxygen isotopes was used for palaeotemperature reconstruction. In this case the isotope equilibrium may be expressed as [20]:

$$
10^{3} \ln \alpha_{\mathrm{CaCO}_{3}-\mathrm{H}_{2} \mathrm{O}}=2.78 \cdot 10^{6} T^{-2}-2.89
$$

Similarly as in the case of stable isotopes of carbon, the value of the fractionation coefficient was calculated from equation:

$$
\alpha_{\mathrm{CaCO}_{3}-\mathrm{H}_{2} \mathrm{O}}=\frac{\delta^{18} \mathrm{O}_{\mathrm{CaCO}_{3}}+1000}{\delta^{18} \mathrm{O}_{\mathrm{H}_{2} \mathrm{O}}+1000}
$$

As $\delta^{18} \mathrm{O}_{\mathrm{CaCO}_{3}}$ were accepted determinations for calcareous tufa, whereas the $\delta^{18} \mathrm{O}_{\mathrm{H}_{2} \mathrm{O}}$ value was accepted as a fixed value corresponding to the average value of the ratio of stable isotopes of oxygen in groundwater supplying the springs in the vicinity of the cupola. In Equation (18), $\delta^{18} \mathrm{O}$ values for water and calcite should be expressed in relation to the same standard. The temperature of calcite precipitation was calculated according to equation:

$$
T\left[{ }^{\circ} \mathrm{C}\right]=\sqrt{\frac{2.78 \cdot 10^{6}}{10^{3} \ln \alpha+2.89}}-273.15
$$

\section{Results}

The achieved results indicate that waters of the Cretaceous and Quaternary formations have a composition typical of hypergenic zones They represent typical freshwater with mineralisation not exceeding $550 \mathrm{mg} / \mathrm{L}$ (averagely $418.9 \mathrm{mg} / \mathrm{L}$ ), representing the $\mathrm{HCO}_{3}-\mathrm{Ca}$ and subordinately $\mathrm{HCO}_{3}-\mathrm{SO}_{4}-\mathrm{Ca}$ types (Table 1). Differences in the ionic composition can be observed between the Upper Cretaceous and the Quaternary. Quaternary waters contain more sulphates and (to a lesser degree) magnesium.

$\delta^{18} \mathrm{O}$ and $\delta^{2} H$ determinations in the analysed groundwater (Table 2) are within the range of $-11.43--9.35 \%$ o (averagely $-10.29 \%$ o) and $-78.89--72.27 \%$ o (averagely $-76.56 \%$ o). The obtained range of $\delta^{18} \mathrm{O} \%$ o values corresponds to the range typical of precipitation water registered in stations located on continental areas. At average annual atmospheric temperature in the range of $8-10{ }^{\circ} \mathrm{C}, \delta^{18} \mathrm{O}$ values in precipitation water are typically within $-9 \%$ o- $-11 \%$, as confirmed also by data from Poland [21,22]. The obtained results indicate that the groundwaters studied are infiltration waters, and the main factor influencing the fractionation of stable isotopes of oxygen is atmospheric temperature. The infiltration origin of the water is also indicated by the fact that the results of $\delta^{18} \mathrm{O}$ coupled with values of $\delta^{2} \mathrm{H}$ are close to the global meteoric water line (GMWL) (Figure 3). Spatial diversity of the isotopic composition results from the infiltration of meltwater and variable in time intensity of evapotranspiration [23]. 
Table 1. Chemical composition of the analysed groundwater.

\begin{tabular}{|c|c|c|c|c|c|c|c|c|c|c|c|c|c|c|c|c|}
\hline \multirow{2}{*}{$\begin{array}{l}\text { Point } \\
\text { Number }\end{array}$} & \multirow{2}{*}{ Stratygraphy } & \multirow{2}{*}{$\begin{array}{c}\text { Temperature } \\
\left({ }^{\circ} \mathrm{C}\right) \\
\end{array}$} & \multirow{2}{*}{$\frac{\mathrm{pH}}{-}$} & \multirow{2}{*}{$\frac{\text { Eh }}{(\mathrm{mV})}$} & \multirow{2}{*}{$\frac{\text { SEC }}{(\mu \mathrm{S} / \mathrm{cm})}$} & $\mathrm{Ca}^{2+}$ & $\mathrm{Mg}^{2+}$ & $\mathrm{Na}^{+}$ & $\mathrm{K}^{+}$ & $\mathrm{NH}_{4}^{+}$ & $\mathrm{Cl}^{-}$ & $\mathrm{HCO}_{3}^{-}$ & $\mathrm{SO}_{4}{ }^{2-}$ & $\mathrm{NO}_{3}{ }^{-}$ & $\mathrm{NO}_{2}{ }^{-}$ & TDS \\
\hline & & & & & & \multicolumn{11}{|c|}{$(\mathrm{mg} / \mathrm{L})$} \\
\hline 1 & $\mathrm{~K}_{2}$ & 9.9 & 7.78 & -47 & 402 & 72.3 & 5.1 & 5.6 & 1.5 & 0.51 & 3.2 & 311.1 & 0.6 & $<0.01$ & 0.08 & 400.0 \\
\hline 2 & $\mathrm{~K}_{2}$ & 9.3 & 7.38 & -88 & 382 & 64.5 & 3.6 & 3.3 & 0.9 & 0.19 & 9.1 & 231.8 & 13.6 & $<0.01$ & 0.065 & 327.1 \\
\hline 3 & $\mathrm{Q}$ & 9.9 & 7.36 & -46 & 594 & 91.8 & 7.5 & 9.8 & 3.3 & 0.302 & 23 & 298.9 & 55.7 & $<0.01$ & 0.08 & 490.4 \\
\hline 4 & Q & 9.9 & 7.47 & 89 & 407 & 69.5 & 3 & 3.4 & 0.7 & $<0.001$ & 10.1 & 183 & 33.5 & 21.79 & 0.073 & 325.1 \\
\hline 5 & Q & 9.8 & 7.3 & -96 & 608 & 117.2 & 6.1 & 10.3 & 1.6 & $<0.001$ & 38.9 & 244 & 112.7 & $<0.01$ & 0.026 & 530.8 \\
\hline 6 & $\mathrm{Q}$ & 9.7 & 7.24 & -97 & 496 & 100.8 & 5.5 & 8.1 & 1.9 & 0.234 & 38.9 & 244 & 41.3 & $<0.01$ & 0.094 & 440.8 \\
\hline 7 & Q & 9.9 & 7.2 & -3 & 663 & 111.3 & 5.7 & 11.2 & 5.1 & 0.025 & 27 & 256.2 & 111.3 & 0.6 & 0.134 & 528.6 \\
\hline 8 & $\mathrm{~K}_{2}$ & 10.9 & 7.2 & -79 & 545 & 95.7 & 8 & 5 & 1.6 & 2.14 & 5.7 & 390.4 & 6.8 & $<0.01$ & 0.08 & 515.4 \\
\hline 9 & Q & 9.9 & 7.49 & -28 & 357 & 63.3 & 3.2 & 5.4 & 2.1 & 0.044 & 10.6 & 170.8 & 39.5 & 1.62 & 0.092 & 296.7 \\
\hline 10 & $\mathrm{~K}_{2}$ & 9.6 & 7.4 & -69 & 487 & 88.3 & 7 & 4.8 & 1.4 & 0.293 & 5.2 & 359.9 & 6.8 & $<0.01$ & 0.027 & 473.7 \\
\hline 11 & Q & 10.4 & 1.66 & 217 & 472 & 71.1 & 2.4 & 6.6 & 2.2 & $<0.001$ & 15.6 & 97.6 & 47.9 & 57.18 & 0.08 & 300.7 \\
\hline 12 & Q & 9.5 & 7.05 & 128 & 450 & 85.5 & 4.1 & 4 & 0.4 & $<0.001$ & 5.6 & 280.6 & 17.1 & $<0.01$ & $<0.001$ & 397.3 \\
\hline \multicolumn{2}{|r|}{ Mean } & 9.9 & 7.38 & -9.9 & 488.6 & 85.9 & 5.1 & 6.5 & 1.9 & 0.31 & 16.1 & 255.7 & 40.6 & 20.30 & 0.08 & 418.9 \\
\hline \multicolumn{2}{|c|}{ Standard deviation } & 0.4 & 0.20 & 96.9 & 92.9 & 17.4 & 1.8 & 2.6 & 1.2 & 0.6 & 12.3 & 77.9 & 36.2 & 22.9 & 0.0 & 86.3 \\
\hline
\end{tabular}


Table 2. Determinations of stable isotopes of oxygen and carbon in groundwater with calculations of chemical and isotope equilibrium with regard to the main speciations of carbon dioxide.

\begin{tabular}{|c|c|c|c|c|c|c|c|c|c|c|c|c|}
\hline \multirow{2}{*}{$\begin{array}{l}\text { Sampling } \\
\text { Points }\end{array}$} & \multicolumn{5}{|c|}{ Measured Values } & \multicolumn{7}{|c|}{ Calculated Values } \\
\hline & $\begin{array}{l}\text { Temperature } \\
\text { (K) }\end{array}$ & $\delta^{18} \mathrm{O}(\% \mathrm{o})$ & $\delta^{18} \mathrm{O}(\% \mathrm{o})$ & $\begin{array}{c}\delta^{13} \mathrm{C}_{\mathrm{DIC}} \\
(\% \mathrm{o})\end{array}$ & $\begin{array}{c}D I C \\
(\mathrm{~mol} / \mathrm{L})\end{array}$ & $\begin{array}{c}m \mathrm{CO}_{3} \\
(\mathrm{~mol} / \mathrm{L})\end{array}$ & $\begin{array}{c}m \mathrm{HCO}_{3} \\
(\mathrm{~mol} / \mathrm{L})\end{array}$ & $\begin{array}{c}m \mathrm{CO}_{2(\mathrm{aq})} \\
(\mathrm{mol} / \mathrm{L})\end{array}$ & $\delta^{13} \mathrm{C}_{\mathrm{CO}_{3}}(\%$ o) & $\delta^{13} \mathrm{C}_{\mathrm{HCO}_{3}}(\%$ o $)$ & $\mathcal{\delta}^{13} \mathrm{C}_{\mathrm{CO}_{2}(\mathrm{aq})}(\% \mathrm{o})$ & $\delta^{13} \mathrm{C}_{\mathrm{CO}_{2}(\mathrm{~g})}(\% \mathrm{o}$ \\
\hline 1 & 283.05 & -11.43 & -75.71 & -13.46 & $5.10 \times 10^{-3}$ & $2.77 \times 10^{-5}$ & $4.86 \times 10^{-3}$ & $2.13 \times 10^{-4}$ & -15.17 & -13.02 & -23.59 & -22.49 \\
\hline 2 & 282.45 & -10.40 & -76.20 & -13.53 & $3.80 \times 10^{-3}$ & $7.15 \times 10^{-6}$ & $3.41 \times 10^{-3}$ & $3.84 \times 10^{-4}$ & -14.62 & -12.44 & -23.09 & -21.99 \\
\hline 3 & 283.05 & -10.48 & -74.57 & -12.92 & $4.90 \times 10^{-3}$ & $1.06 \times 10^{-5}$ & $4.39 \times 10^{-3}$ & $5.00 \times 10^{-4}$ & -13.98 & -11.82 & -22.41 & -21.31 \\
\hline 4 & 283.05 & -10.53 & -74.34 & -13.06 & $3.00 \times 10^{-3}$ & $7.41 \times 10^{-6}$ & $2.75 \times 10^{-3}$ & $2.48 \times 10^{-4}$ & -14.34 & -12.19 & -22.77 & -21.67 \\
\hline 5 & 282.95 & -10.48 & -72.27 & -12.62 & $4.00 \times 10^{-3}$ & $8.21 \times 10^{-6}$ & $3.53 \times 10^{-3}$ & $4.59 \times 10^{-4}$ & -13.55 & -11.39 & -22.00 & -20.89 \\
\hline 6 & 282.85 & -9.96 & -78.57 & -13.19 & $4.00 \times 10^{-3}$ & $6.66 \times 10^{-6}$ & $3.47 \times 10^{-3}$ & $5.24 \times 10^{-4}$ & -13.96 & -11.79 & -22.41 & -21.30 \\
\hline 7 & 283.05 & -10.22 & -78.48 & -13.49 & $4.20 \times 10^{-3}$ & $6.48 \times 10^{-6}$ & $3.60 \times 10^{-3}$ & $5.90 \times 10^{-4}$ & -14.15 & -11.99 & -22.58 & -21.48 \\
\hline 8 & 284.05 & -9.35 & -77.90 & -14.09 & $6.40 \times 10^{-3}$ & $9.92 \times 10^{-6}$ & $5.50 \times 10^{-3}$ & $8.87 \times 10^{-4}$ & -14.76 & -12.64 & -23.10 & -22.00 \\
\hline 9 & 283.05 & -10.36 & -78.65 & -12.46 & $2.80 \times 10^{-3}$ & $6.94 \times 10^{-6}$ & $2.57 \times 10^{-3}$ & $2.22 \times 10^{-4}$ & -13.78 & -11.62 & -22.21 & -21.11 \\
\hline 10 & 282.75 & -9.67 & -78.89 & -14.17 & $5.90 \times 10^{-3}$ & $1.39 \times 10^{-5}$ & $5.33 \times 10^{-3}$ & $5.60 \times 10^{-4}$ & -15.33 & -13.16 & -23.77 & -22.67 \\
\hline 11 & 283.55 & - & - & -13.82 & $1.60 \times 10^{-3}$ & $6.46 \times 10^{-6}$ & $1.51 \times 10^{-3}$ & $8.68 \times 10^{-4}$ & -15.36 & -13.22 & -23.74 & -22.64 \\
\hline 12 & 282.65 & - & - & -15.35 & $4.60 \times 10^{-3}$ & $4.23 \times 10^{-6}$ & $3.71 \times 10^{-3}$ & $8.82 \times 10^{-4}$ & -15.48 & -13.30 & -23.93 & -22.82 \\
\hline
\end{tabular}




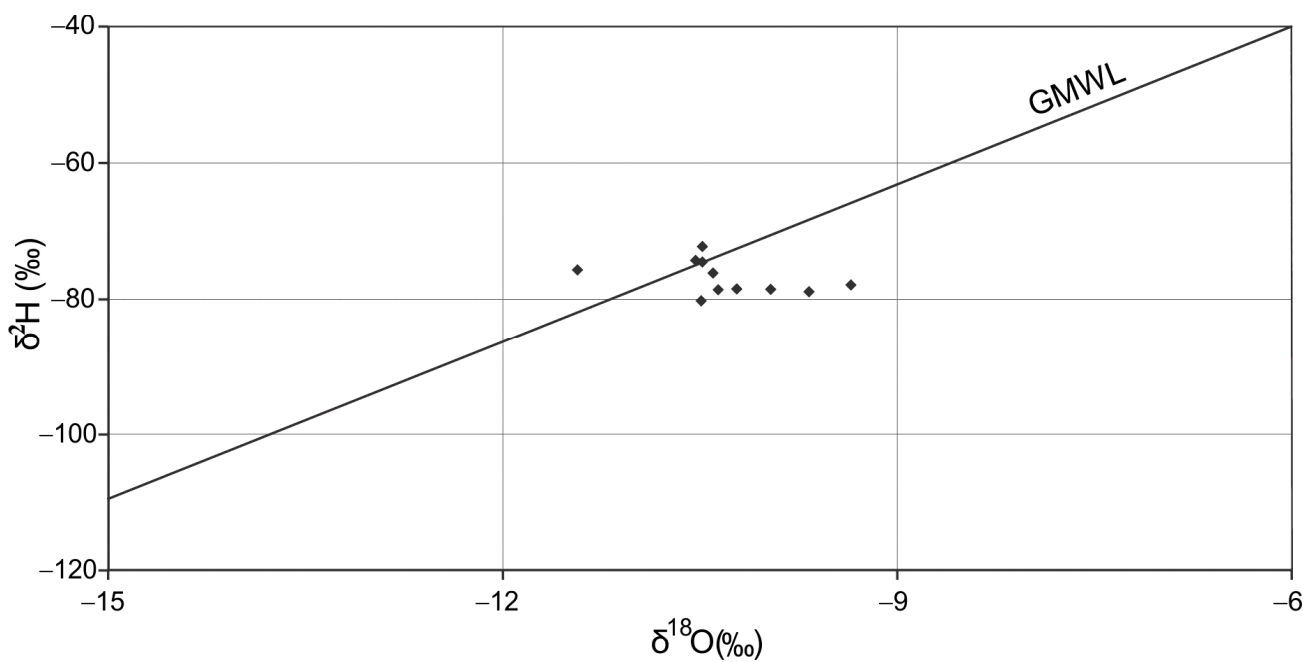

Figure 3. $\delta^{18} \mathrm{O}$ and $\delta^{2} \mathrm{H}$ determinations of the studied groundwaters in relation to the global meteoric water line $(G M W L)$.

$\delta^{13} \mathrm{C}_{\text {DIC }}$ values (Table 2) are within the range from -12.46 to $-15.35 \%$, with an average value of $-13.51 \%$ o. Calculation results (Table 2) indicate that the dominating speciation in the groundwaters studied is $\mathrm{HCO}_{3}$. At the same time, this component is characterised by a higher contribution of ${ }^{13} \mathrm{C}$ compared to DIC. The remaining speciations, particularly $\mathrm{CO}_{2(\mathrm{aq})}$, are according to model calculations significantly impoverished in the heavier isotope. With regard to this, particularly interesting are calculation results for gaseous carbon dioxide. $\delta^{13} \mathrm{C}_{\mathrm{CO} 2(\mathrm{~g})}$ attains values within $-20.89--22.82 \%$ o and thus very close to the average value in the soil carbon dioxide $(-23 \%$ o) of temperate latitudes, i.e. in areas with a dominating contribution of plants, whose photosynthesis follows the Calvin cycle [11].

$\delta^{18} \mathrm{O}$ for calcite in samples of calcareous tufa attained values between $-7.18--7.69 \%$, and $\delta^{13} \mathrm{C}$ - between -8.38--9.65\% (Figure 4). These data were used in an attempt to reconstruct the changes of water temperature in the outflow zone. The thermometer based on oxygen indicated that the oldest tufa series (A) was formed at conditions much cooler than presently. According to the indication of this thermometer, water temperature in the outflow zone was about $6{ }^{\circ} \mathrm{C}$. At present, groundwater in the outflow zone is characterised by low temperature oscillations. Between 2011-2016, regardless the time of the year at which the measurements were made, the registered temperatures were between 9.4-9.9 ${ }^{\circ} \mathrm{C}$ (averagely $9.6^{\circ} \mathrm{C}$ ), which is a value close to the average annual atmospheric temperature in this area $\left(9.0^{\circ} \mathrm{C}\right.$ between $2007-2016$, synoptic meteorological station in Łódź). The carbon thermometer points to an even lower temperature of tufa formation from series $\mathrm{A}\left(4^{\circ} \mathrm{C}\right)$ and, despite the fact that this result should be treated with caution, it evidently confirms distinct cooling of atmospheric temperature, and thus also of groundwater, at the end of the Atlantic period. Younger series of calcareous tufa represent deposits of much warmer intervals, although according to the indication of the oxygen thermometer, still lower by $1-2{ }^{\circ} \mathrm{C}$ from the present day values. At the same time, according to the indication of the oxygen thermometer, the amplitude of temperature oscillations in the Subboreal (i.e. during the formation of calcareous tufa from series B, C and D) did not exceed $2{ }^{\circ} \mathrm{C}$. A completely different scenario was obtained from the carbon thermometer. Despite the fact that this thermometer also indicates that distinct climate warming took place after deposition of series A tufa, the reconstructed temperature range is much wider, and the temperature oscillations have a different course in time. 


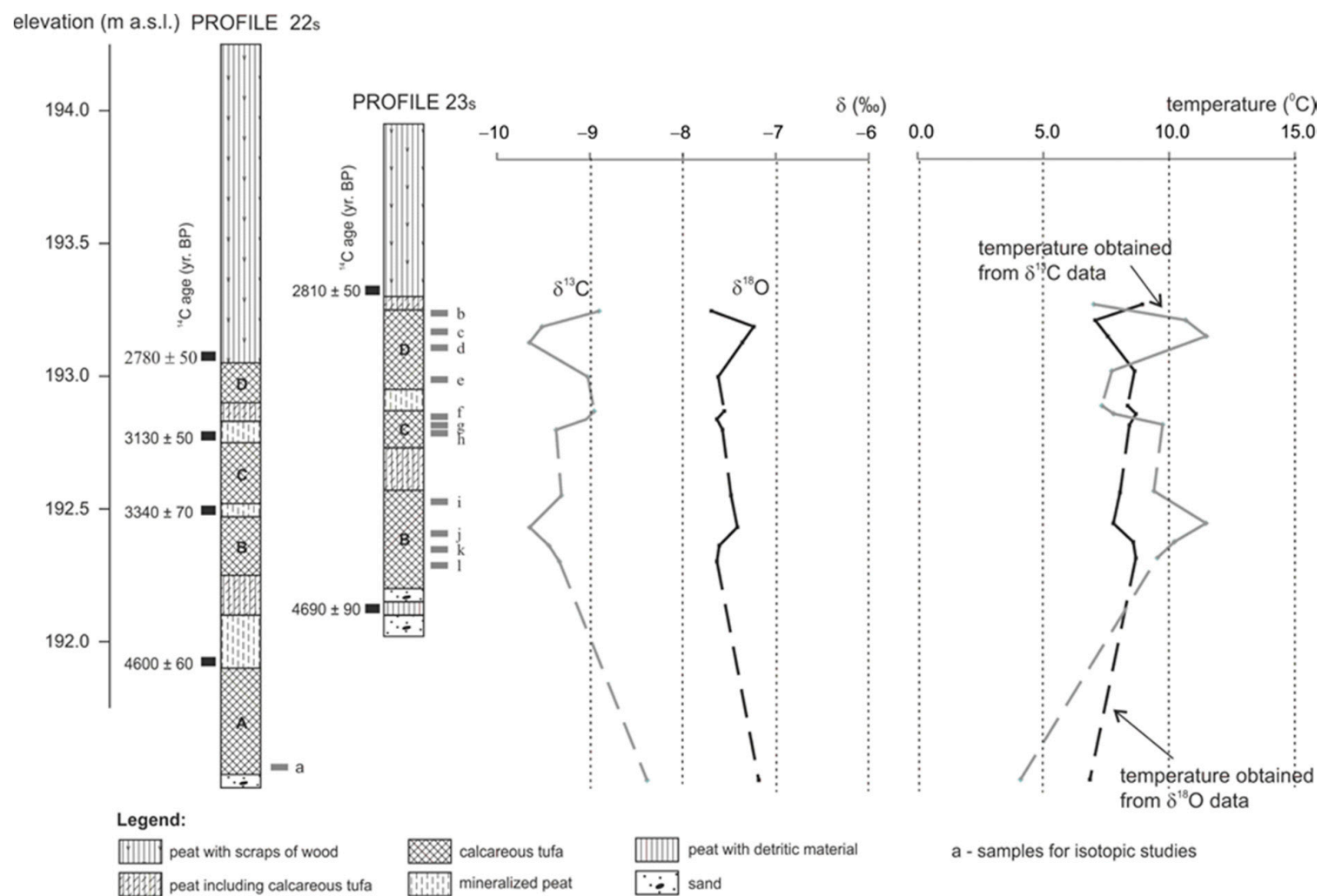

Figure 4. Determinations of stable isotopes of oxygen and carbon in calcite and temperatures obtained on their basis.

Analysis of variability in time required dating the calcareous tufa samples, in which determinations of $\delta^{18} \mathrm{O}$ and $\delta^{13} \mathrm{C}$ were made in calcite. Radiocarbon age determinations in peat (Table 3) were used in this case. After calibration of the sample ages using the IntCal 13 curve, a sedimentary rate model was constructed (Figure 5). This allowed for recalculating the depth of tufa samples on the calibrated radiocarbon age.

Table 3. Radiocarbon determinations and dates calibrated with IntCal13 curve.

\begin{tabular}{|c|c|c|c|c|}
\hline \multirow{2}{*}{ Profile Number } & \multirow{2}{*}{ Depth [m] } & \multirow{2}{*}{$\begin{array}{c}\text { Radiocarbon Determination } \\
\text { (Years BP) }\end{array}$} & \multicolumn{2}{|c|}{ Calibrated Date [BP] } \\
\hline & & & $68.2 \%$ Probability & 95.4\% Probability \\
\hline 23 & 0.63 & $2810 \pm 50$ & $2975-2850(68.2 \%)$ & 3059-2789 (95.4\%) \\
\hline 23 & 1.83 & $4690 \pm 90$ & $\begin{array}{l}5577-5535(13.2 \%) \\
5479-5319(55.0 \%)\end{array}$ & $\begin{array}{l}5605-5272(90 \%) \\
5183-5120(3.1 \%) \\
5112-5066(2.4 \%)\end{array}$ \\
\hline 22 & 1.18 & $2780 \pm 50$ & $\begin{array}{l}2946-2843(59 \%) \\
2820-2800(9.2 \%)\end{array}$ & 2998-2769 (95.4\%) \\
\hline 22 & 1.48 & $3130 \pm 50$ & $\begin{array}{c}3440-3433(2.7 \%) \\
3401-3325(44.3 \%) \\
3295-3253(21.1 \%)\end{array}$ & $3450-3220(95.4 \%)$ \\
\hline 22 & 1.76 & $3340 \pm 70$ & $\begin{array}{c}3679-3670(2.8 \%) \\
3641-3479(65.4 \%)\end{array}$ & $\begin{array}{c}3820-3794(1.9 \%) \\
3761-3752(0.5 \%) \\
3725-3440(90.5 \%) \\
3433-3400(2.5 \%)\end{array}$ \\
\hline 22 & 2.33 & $4600 \pm 60$ & $\begin{array}{c}5459-5375(31.4 \%) \\
5331-5280(21.8 \%) \\
5164-5135(7.8 \%) \\
5105-5076(7.3 \%)\end{array}$ & $\begin{array}{c}5569-5559(0.8 \%) \\
5471-5212(68.4 \%) \\
5193-5050(26.2 \%)\end{array}$ \\
\hline
\end{tabular}




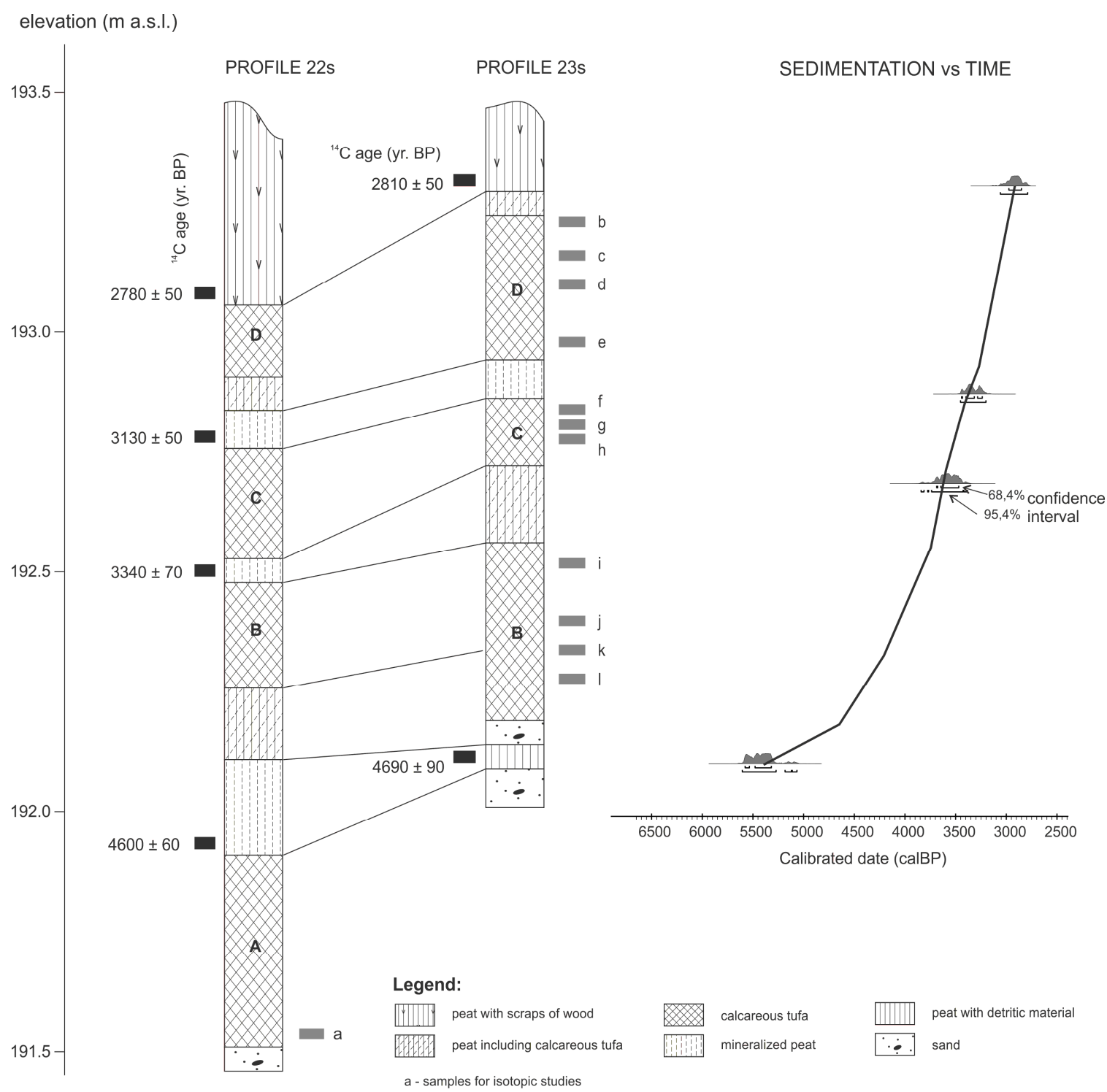

Figure 5. Sedimentary rate model constructed with the use of OxCal software [14] based on the IntCal 13 curve.

\section{Discussion}

Previous studies of deposits within the spring mire cupola at Wardzyń [9] have allowed for correlating the sedimentary succession with variably humidity conditions in the Subboreal. Analysis of the sedimentary succession and mineral composition of the tufas have allowed to relate them with periods of relatively low precipitation, whereas the peats seem to represent more humid intervals. It was assumed that calcite dominating in the tufa composition was formed by balancing of groundwater flowing to the surface with atmospheric carbon dioxide, and the tufas represent a chemical deposit that was formed within the spring basin. The presented results of stable isotope analysis of carbon confirm this hypothesis. The chemical and isotopic composition, and the temperature of contemporary groundwater have enabled calculating the theoretical values of $\delta^{13} \mathrm{C}$ in calcite that could be precipitated by balancing these waters with atmospheric carbon dioxide. The obtained theoretical values of $\delta^{13} \mathrm{C}_{\mathrm{CaCO}}$ in relation to the analysed 12 groundwater samples are between -8.39 and $-10.30 \%$. This range is very similar to that obtained for empirical measurements reformed in relation to calcite in calcareous tufas of the cupola $(-8.38--9.65 \%$ o). Similarity of these results evidences that calcite was formed as a chemical deposit, and isotope fractionation mostly depended on the temperature. 
Results of tufa analysis were used to interpret the temperature of the environment in the Subboreal, with application of the chemical and isotope equilibrium model. This model, however, has certain restrictions. The basic limit is the lack of knowledge on the chemical composition and stable isotope ratios in groundwater during the Subboreal. In some cases it is possible to reconstruct isotope ratios in water based on the isotope composition of organic matter in sediments. A good example is the isotope determination of oxygen in cellulose. The results of experimental work indicate that the fractionation coefficient of oxygen isotopes between cellulose formed as a result of photosynthesis of aquatic plants and water is constant and does not depend on temperature, plant species or type of photosynthesis [24]. This allows reconstruction of the isotope composition of water, based on $\delta^{18} \mathrm{O}$ determinations in cellulose present in lake sediments. However, in the case of the studied cuppola, organic matter present in the calcareous tufa contains an admixture of allochtonic material and this technique could not be used. For this reason it was necessarily assumed that this composition did not differ significantly from present day waters, and average values calculated on the basis of $\delta^{18} \mathrm{O}_{\mathrm{H} 2 \mathrm{O}}$ and $\delta^{13} \mathrm{C}_{\mathrm{DIC}}$ determinations in present day waters were used in the calculations. This means that the temperatures obtained both from the carbon and oxygen thermometers should not be treated as absolute values. However, due to the low variability of ratios of stable isotopes in DIC in present day groundwater, they allow for indicative tracing of changes in the environmental temperatures in the groundwater outflow zone during the Subboreal.

Temperatures reconstructed based on carbon and oxygen isotope thermometers indicate that the oldest calcareous tufa series was formed in cold climate conditions, whereas the younger series developed when the atmospheric temperature did not differ much from present day values. In this part of the succession, however, temperatures reconstructed with the use of both thermometers show a variable course of changes in time. This most probably results from the sensitivity of the fractionation process of stable isotopes of carbon to biotic factors. If both temperature and humidity changed during the formation of the cupola deposits, it may be assumed that these changes were accompanied by transformation of the vegetation cover. Potential transformation of the soil layer could thus also have influence on the fractionation of carbon isotopes both in soil carbon dioxide and in groundwater. Variability of isotope ratios could also be influenced by variable biotic conditions in the spring basin. Here, both macrophytes and phytoplankton developing within the spring basin could have had influence on isotope fractionation [25]. In such conditions, isotope fractionation in calcite was not only the function of temperature, and thus the results of the applied model remain dubious and may be treated only as indicative. Therefore, results from the oxygen thermometer were considered as more reliable and the attempt to evaluate the thermal changes of the environment in time was based on them.

By calibrating the age of the tufa samples, it was possible to compare temperatures reconstructed from the oxygen thermometer with temperature curves obtained in other sites. $\delta^{18} \mathrm{O}$ values for the tufa from the spring mire cupola in Wardzyń obtained by Dobrowolski et al. [5] were also used in the comparison; temperature values were calculated with the same methodology as for the determinations presented in this report (Figure 6). The obtained curves were compared with the GISP2 Ice Core Temperature and Accumulation Data curve [2,3]. The results indicate a similar trend of thermal changes in the environment with time. The cooling and warming episodes recorded in Greenland (op.cit.) are clearly reflected in the temperature curves obtained for the spring mire cupola in Wardzyń, with two clearly marked cool episodes at about 3000 and about 3900 cal years BP, separated by a slightly warmer period. A similar trend was also observed in Northern Europe. Based on thermometers using pollen analysis, chironomids and stable isotopes in lacustrine deposits, Seppa et al. [1] (2009) distinguished cool episodes between 3000-3900 cal years BP. Similar results were obtained by Stansell et. al. [7] based on $\delta^{18} \mathrm{O}$ determinations; they also evidenced that the largest temperature oscillations in the Subboreal took place in the summer months. A very similar course of temperature curves for Central and Eastern Europe was presented by Davies et al. [4]. They elaborated averaged temperature curves based on a qualitative reconstruction of pollen analysis from over 500 sites in Europe. The curve of average annual temperature for Central and Eastern Europe has a very similar trend to that obtained 
from the Wardzyń deposits, with two cool episodes at about 3900 and about 2900 cal years BP, with the cooling particularly occurring in the summer months. A similar course have also temperature curves obtained on the basis of stable oxygen isotopes in calcareous tufa from the Czech Republic and southern Poland [6,8]. Temperature changes reconstructed based on the isotope analysis of deposits from Wardzyń correspond well also with other sites from Poland. The analysis of probability density for various types of Holocene deposits [26] indicates that between 4850-3700 cal years BP, gradual climate cooling and aridification took place. Next, a warm phase began, which ended about $2850 \mathrm{cal}$ years BP. A very similar trend is visible on the temperature curve from Wardzyń (Figure 6), on which the cooler episodes at about 3900 and about 2900 cal years BP mark the limits of an interval with distinctly higher temperatures during the Late Subboreal (SB2). Transition from cool climate to much warmer conditions at about 3900 cal years BP is also confirmed by isotope analysis of calcite from lacustrine deposits. Temperature curves obtained for the Gościąż Lake [27] indicate that the change of thermal conditions was rapid and took place after 3900 cal years BP.

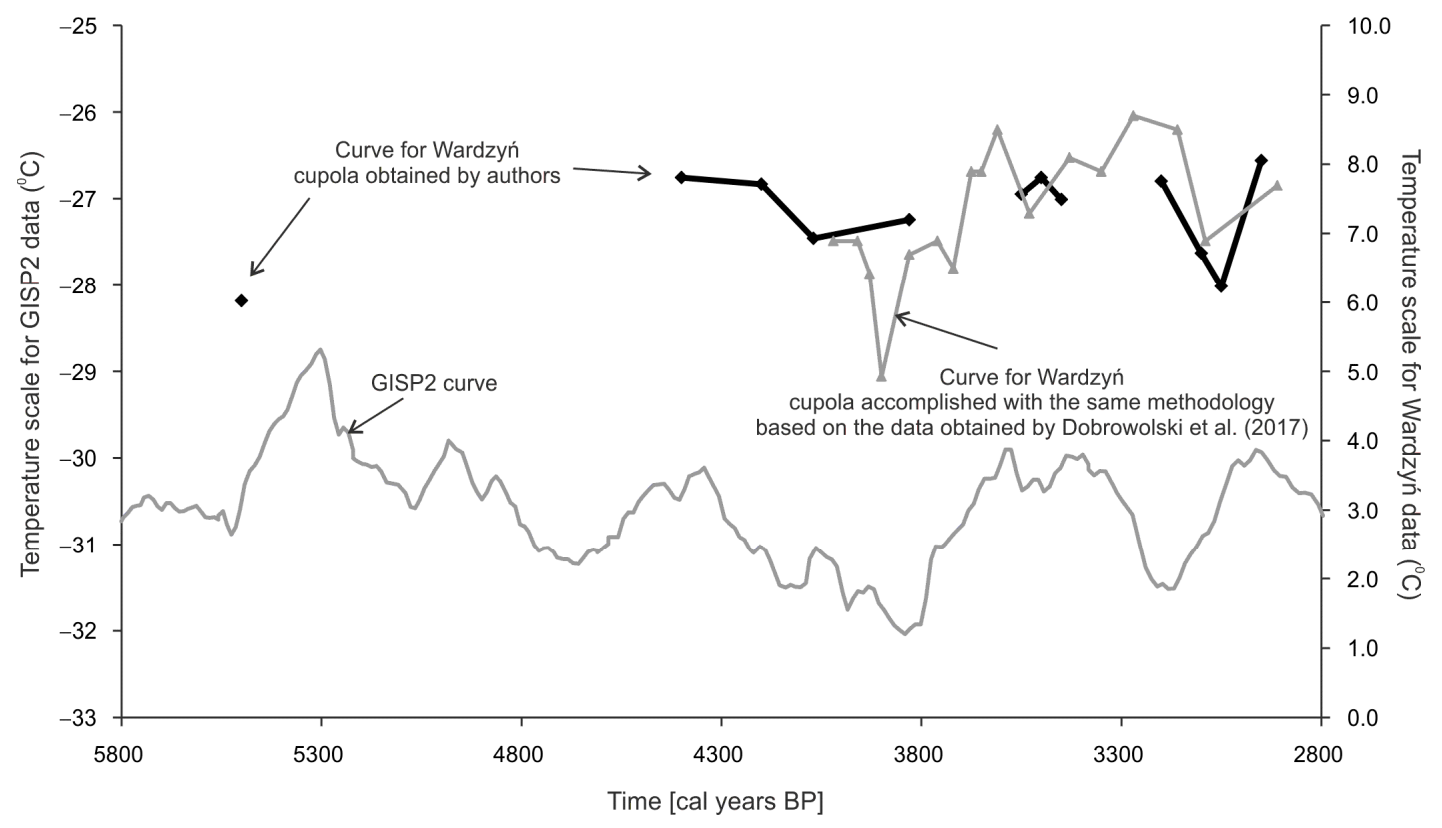

Figure 6. Comparison of the GISP2 curve with temperatures based on stable oxygen isotopes from calcareous tufa samples from Wardzyń. The figure presents also temperatures obtained by Dobrowolski et al. [5] based on $\delta^{18} \mathrm{O}$ from the neighbouring core in the same cupola.

\section{Conclusions}

The model presented in this paper, based on chemical and isotope equilibrium in relation to stable isotopes of carbon has allowed for calculating $\delta^{13} \mathrm{C}$ with regard to the main speciation forms of carbon dioxide in the solution and to gaseous carbon dioxide remaining in equilibrium with the solution. The obtained results are very similar to $\delta^{13} \mathrm{C}$ values in soil carbon dioxide in areas covered by vegetation, in which photosynthesis follows the Calvin cycle. Because the plant communities in the study area represent a similar type of vegetation, this lends credence to the obtained results. Moreover, these results indicate that dissolution of carbonates in the system studied is similar to that from open carbonate systems. This means that carbon isotope fractionation is largely controlled by temperature. Based on this assumption, the theoretical values of $\delta^{13} \mathrm{C}$ in calcite were calculated; their levels were similar to those obtained for calcite from samples of calcareous tufa. This confirms the hypothesis of the chemical nature of the calcite (formation without the contribution of living organisms) in effect of balancing the groundwater solution with atmospheric carbon dioxide in the outflow zone (spring basin). This justifies the application of stable isotopes of oxygen and carbon in palaeotemperature reconstructions during the Subboreal (i.e. the interval during which the calcareous tufa was formed). Due to the complexity 
of the carbon fractionation process and the related interpretative issues, results based on $\delta^{13} \mathrm{C}$ were treated as indicative, the main importance being attributed to $\delta^{18} \mathrm{O}$.

The calculations indicate that the oldest calcareous tufa (series A) was formed about $5500 \mathrm{cal}$ years BP in a dry and significantly cooler climate compared to present day conditions. The formation of subsequent series of calcareous tufa took place between 4400 and 2900 cal years BP, at thermal conditions only slightly lower compared to present day values, with two distinct cooling episodes at about 3900 and 3000 cal years BP. The course of the obtained temperature curves correlates well with the GISP2 curve obtained from the ice core in Greenland and other sites from Northern, and Central and Eastern Europe.

Results of stable isotopes of oxygen and carbon have enabled to supplement the results of previous studies of the spring mire cupola in Wardzyn [9]. Previous analyses of the mineral composition, especially of the sulphur minerals (gypsum and pyrite) accompanying calcite, have allowed to link the calcareous tufa layers with intervals with relatively low precipitation. Analyses based on stable isotopes of carbon and oxygen indicate that the tufas were formed both in cool and warm intervals. This means that the main factor influencing the accumulation of calcite in the spring basin was humidity. At low precipitation, springs in the vicinity of the cupola became less efficient, and the longer time of groundwater contact with atmospheric air favoured balancing of the solution with atmospheric carbon dioxide and in consequence precipitation of calcite. In humid intervals the springs became more effective and conditions favouring peat accumulation developed in the spring basin. In effect, a cupola was formed, which due to the succession of organic and chemical layers is at present a valuable object for palaeoenvironmental reconstructions in the Polish Lowlands for the later parts of the Holocene (particularly the Subboreal).

Author Contributions: Conceptualization: T.G. and J.J.M.; Methodology: T.G. and M.Z.; Investigation: T.G. and M.Z.; Resources: A.R.; Data curation: M.Z. and A.R.; Writing—original draft preparation: T.G.; Writing—review and editing: M.Z.; Visualization: T.G. and A.R.; Supervision: J.J.M.

Funding: This research received no external funding.

Conflicts of Interest: The authors declare no conflict of interest.

\section{References}

1. Seppa, H.; Bjune, A.E.; Telford, R.J.; Birks, H.J.B.; Veski, S. Last Nine-Thousand Years of Temperature Variability in Northern Europe. Clim. Past 2009, 5, 523-535. [CrossRef]

2. Cuffey, K.M.; Clow, G.D. Temperature, Accumulation, and Ice Sheet Elevation in Central Greenland through the Last Deglacial Transition. J. Geophys. Res. 1997, 102, 26383-26396. [CrossRef]

3. Alley, R.B. The Younger Dryas Cold Interval as Viewed from Central Greenland. Quat. Sci. Rev. 2000, 19, 213-226. [CrossRef]

4. Davies, B.A.S.; Brewerb, S.; Stevensona, A.C.; Guiotc, J. The Temperature of Europe during the Holocene Reconstructed from Pollen Data. Quat. Sci. Rev. 2003, 22, 1701-1716. [CrossRef]

5. Dobrowolski, R.; Ziułkiewicz, M.; Okupny, D.; Forysiak, J.; Bałaga, K.; Alexandrowicz, W.P.; Buczek, A.; Hałas, S. Origin and Neoholocene Evolution of Spring-Fed Fens in Wardzyń, Łódź Upland, Central Poland. Golog. Q. 2017, 61, 413-434.

6. Pazdur, A.; Pazdur, M.F.; Starkel, L.; Szulc, J. Stable Isotopes of Holocene Calcareous Tufa in Southern Poland as Paleoclimatic Indicators. Quat. Res. 1988, 30, 177-189. [CrossRef]

7. Stansell, N.D.; Klein, E.S.; Finkenbinder, M.S.; Fortney, C.S.; Dodd, J.P.; Terasmaa, J.; Nelson, D.B. A Stable Isotope Record of Holocene Precipitation Dynamics in the Baltic Region from Lake Nuudsaku, Estonia. Quat. Sci. Rev. 2017, 175, 73-84. [CrossRef]

8. Zak, K.; Lozek, V.; Kadlec, J.; Hladikova, J.; Cilek, V. Climate-Induced Changes in Holocene Calcareous Tufa Formations, Bohemian Karst. Quat. Int. 2002, 91, 137-152. [CrossRef]

9. Gruszczyński, T.; Małecki, J.J.; Ziułkiewicz, M. Reconstruction of Paleohydrological Conditions in the Late Holocene Based on the Study of Calcareous Tufa in the Spring Mire of the Wolbórka River Drainage Basin (Central Poland). J. Elem. 2017, 22, 1049-1065. 
10. Epstein, S.E.; Buchsbaum, R.; Lowenstam, H.A.; Urey, H.C. Revised Carbonate-Water Isotopic Temperature Scale. Geol. Soc. Am. Bull. 1953, 64, 1315-1326. [CrossRef]

11. Clark, I.; Fritz, P. Environmental Isotopes in Hydrogeology; CRC Press: Boca Raton, FL, USA, 1997.

12. Marks, L.; Dzierżek, J.; Janiszewski, R.; Kaczorowski, J.; Lindner, L.; Majecka, A.; Makos, M.; Szymanek, M.; Tołoczko-Pasek, A.; Woronko, B. Quaternary Stratigraphy and Palaeogeography of Poland. Acta Geol. Pol. 2016, 66, 403-427. [CrossRef]

13. Ziułkiewicz, M. Pionowa Strefowość Hydrochemiczna Wód Podziemnych Na Obszarze Aglomeracji Łódzkiej (Vertical Hydrochemical Zonation of Groundwater on the Łódź Metropolitan Area); Łódzkie Towarzystwo Naukowe: Łódź, Poland, 2003.

14. Bronk Ramsey, C. Bayesian Analysis of Radiocarbon Dates. Radiocarbon 2009, 51, 337-360. [CrossRef]

15. Parkhurst, D.L.; Appelo, C.A.J. Description of Input and Examples for PHREEQC Version 3-A Computer Program for Speciation, Batch Reaction, One Dimensional Transport and Inverse Geochemical Calculations; U.S. Geological Survey Techniques and Methods: Reston, VA, USA, 2013; Volume 43.

16. Deines, P.; Langmuir, D.; Harmon, R.S. Stable Carbon Isotope Ratios and the Existence of Gas Phase in the Evolution of Carbonate Groundwaters. Geochim. Cosmochim. Acta 1974, 38, 1147-1164. [CrossRef]

17. Mook, W.G.; Bommerson, J.C.; Staverman, W.H. Carbon Isotope Fractionation between Dissolved Bicarbonate and Gaseous Carbon Dioxide. Earth Planet. Sci. Lett. 1974, 22, 169-176. [CrossRef]

18. Vogel, J.C.; Grootes, P.M.; Mook, W.G. Isotope Fractionation between Gaseous and Dissolved Carbon Dioxide. Z. Phys. 1970, 230, 255-258.

19. Bottinga, Y. Calculation of Fractionation Factors for Carbon and Oxygen in the System Calcite-Carbon Dioxide-Water. J. Phys. Chem. 1968, 72, 800-808. [CrossRef]

20. Friedman, I.; O’Neil, J.R. Compilation of Stable Isotope Fractionation Factors of Geochemical Interest. US Geol. Surv. Bull. 1977, 440, 1-12.

21. D’Obyrn, K.; Grabczak, J.; Zuber, A. Maps of Isotopic Composition of the Holocene Meteoric Waters in Poland (in Polish with English Summary). In Wspótczesne Problemy Hydrogeologii; Adam Mickiewicz University: Poznań, Poland, 1997; Volume 8, pp. 331-333.

22. Różański, K.; Araguas-Araguas, L.; Gonfiantini, R. Isotopic Patterns in Modern Global Precipitation. In Continental Isotope Indicators of Climate; American Geophysical Union Monograph: Warsaw, Poland, 1993.

23. Krogulec, E.; Zabłocki, S.; Sawicka, K. Changes in Groundwater Regime during Vegetation Period in Groundwater Dependent Ecosystems. Acta Geol. Pol. 2016, 66, 525-540. [CrossRef]

24. Sternberg, L.S.L.; Anderson, W.T.; Morrison, K. Separating Soil and Leaf 180 Isotopic Signals in Plant Stem Cellulose. Geochem. Cosmochim. Acta 2003, 67, 2561-2566. [CrossRef]

25. Leng, M.J.; Marshall, J.D. Palaeoclimate Interpretation of Stable Isotope Data from Lake Sediment Archives. Quat. Sci. Rev. 2004, 23, 811-831. [CrossRef]

26. Starkel, L.; Michczyńska, D.J.; Krapiec, M.; Margielewski, W.; Nalepka, D.; Pazdur, A. Progress in the Holocene Chrono-Climatostratigraphy of Polish Territory. Geochronometria 2013, 40,1-21. [CrossRef]

27. Różański, K.; Klisch, M.; Wachniew, P.; Gorczyca, Z.; Goslar, T.; Edwards, T.W.D.; Shemesh, A. Oxygen-Isotope Geothermometers in Lacustrine Sediments: New Insights through Combined $\delta 180$ Analyses of Aquatic Cellulose, Authigenic Calcite and Biogenic Silica in Lake Gościąż, Central Poland. Geochim. Cosmochim. Acta 2010, 74, 2957-2969. [CrossRef]

(C) 2019 by the authors. Licensee MDPI, Basel, Switzerland. This article is an open access article distributed under the terms and conditions of the Creative Commons Attribution (CC BY) license (http://creativecommons.org/licenses/by/4.0/). 